\title{
PEMERTAHANAN SASTRA LISAN LAMPUNG BERBASIS DIGITAL DI KABUPATEN PESAWARAN
}

\author{
Jafar Fakhrurozi, Donaya Pasha $^{2}$, Jupriyadi ${ }^{3}$, Intan Anggrenia ${ }^{4}$ \\ Universitas Teknokrat Indonesia $\mathbf{1 , 2 , 3 , 4}$
}

Email : jafar.fakhrurozi@teknokrat.ac.id ${ }^{1}$, jupriyadi@teknokrat.ac.id², donayapasha@teknokrat.ac.id ${ }^{3}$, intan.anggrenia@teknokrat.ac.id

\begin{abstract}
Received: (16 Februari 2021)
Accepted: (1 Maret 2021)

Published : (30 Maret 2021)

Abstract

This paper describes the Community Service activities carried out on speakers of Lampung oral literature "wawancan" in Way Lima District, Pesawaran Regency. The activity was carried out because of concerns that the development of Lampung oral literature was starting to decline. Therefore, it is necessary to make defense efforts. Maintenance activities that can be carried out in the digital era are by utilizing digital technology through digital documentation, videos and websites. With these efforts, the existence of oral literature is expected to be more developed and accessible to the wider community. The approach used in community service activities is participatory action research (PAR). This method combines research with sustainable action and is carried out in a participatory manner with the community. This method of community service activities is carried out with a variety of approaches, starting from surveys and interviews, documenting oral literature, studying and translating oral literature, and creating websites. The activity was held for three months from August to November 2020. The result of this activity was a process of typing scripts, translation, video documentation products of interview performances, and oral literature websites.
\end{abstract}

Keywords: Defense, Digital, Website, Video, Oral Literature, Wawancan

\begin{abstract}
Abstrak
Tulisan ini menjelaskan kegiatan Pengabdian kepada Masyarakat yang dilakukan terhadap para penutur sastra lisan wawancan Lampung di Kecamatan Way Lima Kabupaten Pesawaran Provinsi Lampung. Kegiatan didasarkan atas adanya kekhawatiran perkembangan sastra lisan Lampung yang mulai menurun. Oleh karena itu perlu dilakukan upaya-upaya pemertahanan. Kegiatan pemertahanan yang dapat dilakukan di era digital seperti sekarang ini dapat dilakukan dengan pemanfaatan teknologi digital melalui dokumentasi digital dan website. Dengan inovasi tersebut keberadaan sastra lisan diharapkan lebih berkembang dan dapat diakses oleh masyarakat secara luas. Pendekatan yang digunakan dalam kegiatan pengabdian kepada masyarakat ini adalah participatory action research (PAR). Metode ini mengkombinasikan antara penelitian dengan tindakan yang berkelanjutan dan dilakukan secara partisipatif bersama masyarakat. Metode pelaksanaan kegiatan pengabdian kepada masyarakat ini dilaksanakan dengan berbagai pendekatan, mulai dari survei dan wawancara, pendokumentasian sastra lisan, pengkajian dan penerjemahan sastra lisan, dan pembuatan website. Kegiatan dilaksanakan selama tiga bulan dari Agustus s.d November 2020. Hasil dari kegiatan ini adalah adanya proses pengetikkan naskah, penerjemahan, produk video dokumentasi pertunjukan wawancan, dan website sastra lisan
\end{abstract}

Kata Kunci: Pemertahanan, Digital, Website, Video, Sastra Lisan, Wawancan

To cite this article:

Authors. (Year). Title of the article. Journal of Technology and Social for Community Service (JTSCS), Vol(1), 27-36.

\section{PENDAHULUAN}

Lampung merupakan salah satu provinsi yang memiliki kekayaan budaya. Salah satunya adalah sastra lisan. Ada berbagai jenis sastra lisan yang masih berkembang hingga saat ini meliputi peribahasa, teka-teki, 
mantra, puisi, dan cerita rakyat. Keberadaan sastra lisan di tengah masyarakat sangat dibutuhkan karena menurut Danandjaja dalam Sukatman, (2009:7), tradisi/sastra lisan mempunyai beberapa fungsi yakni sebagai cerminan angan-angan suatu kelompok masyarakat, sebagai alat pendidikan, sebagai alat pemaksa atau pengontrol normanorma.

Dengan fungsi tersebut maka keberadaan sastra lisan sangat dibutuhkan oleh masyarakat yakni sebagai sarana pewarisan nilai-nilai kultural Lampung. Namun demikian saat ini sastra lisan Lampung kondisinya cukup mengkhawatirkan, termasuk di Kabupaten Pesawaran yang dikenal sebagai daerah penghasil seniman Lampung terutama sastra lisan. Menurut Haris Fadilah saat ini, kebudayaan sastra lisan lampung itu sudah sulit ditemui, bahkan sastrawan yang bias membawakan sastra lisan Lampung itu sudah langka (Yudono, 2010). Hal itu terjadi karena salah satunya dipengaruhi oleh perubahan sosial masyarakat. Masyarakat terutama generasi muda tidak lagi tertarik terhadap sastra lisan, mereka lebih tertarik hiburan lain yang disediakan produk-produk teknologi internet dan digital. Perkembangan zaman tersebut telah membawa perubahan-perubahan di segala bidang termasuk dalam hal kebudayaan. Tradisi mengalami perubahan ketika orang memberikan perhatian khusus pada cerita tertentu dan mengabaikan cerita yang lain. (Azhari, 2018:3).

Herdiyani dalam bukunya Bajidoran di Karawang: Kontinuitas dan Perubahan (2003:140) menyatakan bahwa sebuah kesenian yang hidup di masyarakat akan terus bergulir sejalan dengan arus perkembangan masyarakatnya. Bentuk-bentuk kesenian yang masih relevan dengan zamannya di masyarakat akan tetap hidup dengan berbagai penyesuaian, sedangkan bentuk kesenian yang tidak relevan lagi dengan massanya akan hilang ditelan zaman.

Menurut Mahmud Yunus (2010), keberadaan sastra Lampung merupakan kebudayaan yang sangat indah sehingga dapat dijadikan sarana promosi daerah kepada dunia luar atau daerah lain. Oleh karena itu pemerintah terus berupaya menginventarisasi sastra dan kebudayaan Lampung yang masih berkembang di masyarakat. Namun demikian peran peneliti dan akademisi masih sangat diperlukan.

Dalam kegiatan Pengabdian kepada Masyarakat ini, mitra yang dipilih adalah para penutur sastra lisan Lampung Saibatin di Kabupaten Pesawaran. Masyarakat Lampung sendiri dibagi menjadi dua kelompok besar yaitu pepadun dan Saibatin. Dua adat tersebut dikenal dengan istilah ruwa jurai (dibaca (kh) Khuwa Jurai) yang berarti dua negeri. Masyarakat yang beradat Saibatin memakai dialek (A api/apa) dan masyarakat Pepadun memakai dialek (O nyow/apa).

Sastra lisan yang berkembang pada masyarakat Lampung adalah peribahasa, teka-teki, mantra, puisi, dan cerita rakyat. Salah satu sastra lisan yang masih hidup dalam masyarakat Lampung Saibatin adalah wawancan. Wawancan adalah jenis karya sastra berbentuk puisi/syair/pantun. (Fakhrurozi, 2019:18).

Di lokasi mitra sastra lisan Lampung masih berkembang. Setidaknya, masih banyak para penutur sastra lisan yang masih aktif meskipun intensitasnya sudah berkurang. Jenis sastra lisan yang masih berkembang adalah bubandung, wawancan, tangis, segatta, hahiwang, dan warahan.

Menurut salah satu seniman yang bekerja di Dinas Pendidikan dan Kebudayaan Kabupaten Pesawaran, Jauhari, setidaknya ada 6 penutur sastra lisan yang masih aktif di wilayah Saibatin yakni Saiful Hambala dan Ihsan dari Way Lima, Mega Fafayanti, dan Yurizal Effendi (Kedondong), Muhi ABS (Way Rilau), dan Humandi Abas yang menuturkan Warahan. Penutur tersebut biasanya menguasai beberapa sastra lisan. Menurut Jauhari, keberadaan Meskipun demikian, eksistensi sastra lisan Lampung sudah semakin menurun. Hal ini tentu amat disayangkan mengingat dalam sastra lisan Lampung terdapat identitas dan nilai kultural masyarakat Lampung yang berguna bagi masyarakat.

Masalah lainnya adalah proses pewarisan sastra lisan terhadap generasi muda tidak berjalan mulus. Padahal usia penutur sastra lisan yang masih hidup sudah menginjak lebih dari 60 tahun. Jika dibiarkan maka bukan tidak mungkin sastra lisan Lampung akan punah.

Masalah perkembangan sastra lisan salah satunya ditentukan oleh proses pendokumentasian. Pada kenyataannya kesadaran akan pendokumentasian sastra lisan belum terbangun termasuk pemerintah daerah. Pendokumentasian yang dimaksud adalah pendokumentasian berbasis digital. Naskah wawancan masih dalam bentuk tulisan tangan pada kertas HVS atau kertas folio bergaris. Hal ini sangat rentan karena bisa saja naskah tersebut rusak atau hilang.

Atas dasar itu diperlukan strategi-strategi yang tepat untuk mempertahankan sebuah tradisi. Di tengah perubahan sosial yang serba digital, upaya pemertahanan sastra lisan Lampung harus dilakukan dengan cara-cara yang tepat. Salah satunya adalah dengan pemanfaatan teknologi digital melalui dokumentasi digital dan website. Dengan inovasi tersebut keberadaan sastra lisan diharapkan lebih berkembang dan dapat diakses oleh masyarakat secara luas. 


\section{METODE PELAKSANAAN}

\section{Tempat dan Waktu}

Kegiatan dilaksanakan selama tiga bulan dari Agustus s.d November 2020. Kegiatan bertempat di kediaman seniman (penutur) sastra lisan Saiful Hambala di Desa Baturaja, Kecamatan Way Lima Kabupaten Pesawaran Provinsi Lampung.

\section{Khalayak Sasaran}

Mitra dampingan kegiatan pengabdian kepada masyarakat adalah seniman/penutur sastra lisan Lampung di Kecamatan Way Lima Kabupaten Pesawaran.

\section{Teknik Pengumpulan Data}

Pengumpulan data dilakukan dengan cara wawancara dan pengambilan dokumentasi video. Wawancara dilakukan kepada budayawan dan seniman (penutur) sastra lisan. Rekaman video berisi kegiatan pembacaan wawancan yang dilakukan oleh Saiful Hambala. Ada 3 naskah wawancan yang dibacakan yaitu Wawancan Sejarah Kecamatan Way Lima, Wawancan Nurdin-Ceri, dan Wawancan Jawabni Hulun Tuha.

\section{Metode Pengabdian}

Pendekatan yang digunakan dalam kegiatan pengabdian kepada masyarakat ini adalah participatory action research (PAR). Menurut Kindon dan Ottoson dalam Irawan (2020), metode ini mengkombinasikan antara penelitian dengan tindakan yang berkelanjutan dan dilakukan secara partisipatif bersama masyarakat. Metode PAR dapat dijadikan sebagai upaya upaya untuk memberikan alternatif solusi pemecahan masalah yang dihadapi mitra.

Metode pelaksanaan kegiatan pengabdian kepada masyarakat ini dilaksanakan dengan berbagai pendekatan, mulai dari survei dan wawancara, pendokumentasian sastra lisan, pengkajian dan penerjemahan sastra lisan, dan pembuatan website. Adapun tahapan pelaksanaan dari kegiatan pengabdian kepada masyarakat dapat digambarkan melalui gambar sebagai berikut:

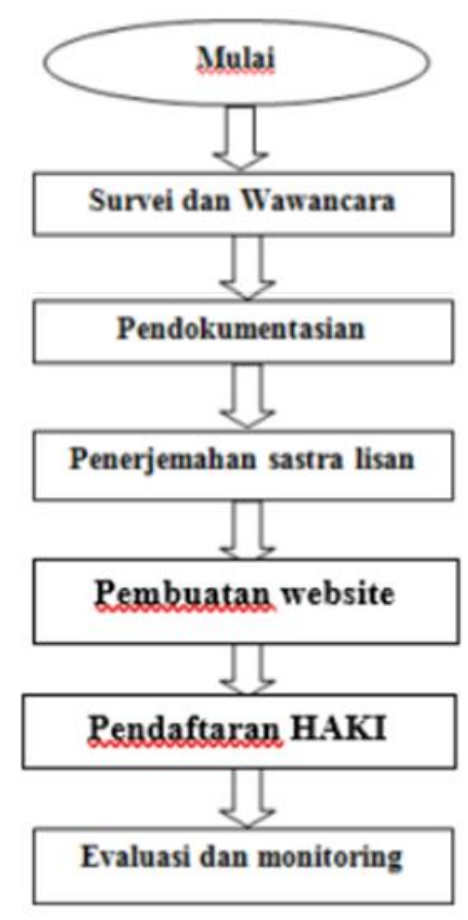

Gambar 1. Tahapan kegiatan pengabdian kepada masyarakat 


\section{HASIL DAN PEMBAHASAN}

Pelaksanaan kegiatan pengabdian kepada masyarakat ini dilaksanakan dalam tiga tahapan sebagai berikut:

\section{Tahap Survei dan Wawancara}

Tahap persiapan diisi dengan kegiatan survei dan wawancara penutur sastra lisan. Survei dan wawancara pertama dilakukan pada 18 Agustus 2020. Wawancara dilakukan kepada budayawan Lampung Jauhari yang berprofesi sebagai Pegawai Dinas Kebudayaan Pemerintah Daerah Kabupaten Pesawaran Jauhari dan seniman/penutur sastra lisan Lampung Saiful Hambala. Survei dan wawancara difokuskan untuk menggali permasalahan mitra. Hasil dari kegiatan tersebut menunjukkan bahwa ada beberapa permasalahan yang dialami mitra. Sastra lisan di daerah Gedong Tataan masih hidup sampai saat ini. Namun eksistensinya sudah semakin menurun. Padahal para penuturnya masih hidup. Selain itu, penutur sastra lisan kurang mendapatkan apresiasi yang layak. Hal itu disebabkan tidak adanya tarif tertentu untuk penutur sastra lisan. Pelestarian sastra lisan juga terkendala oleh dana baik dari penuturnya sendiri maupun pihak eksternal.

Masalah lainnya adalah proses pewarisan sastra lisan terhadap generasi muda tidak berjalan mulus. Jika dibiarkan maka bukan tidak mungkin sastra lisan Lampung akan punah. Sementara masalah utama sebagaimana target kegiatan ini adalah kurangnya proses pendokumentasian. Pada kenyataannya kesadaran akan pendokumentasian sastra lisan belum terbangun termasuk pemerintah daerah. Pendokumentasian yang dimaksud adalah pendokumentasian berbasis digital.

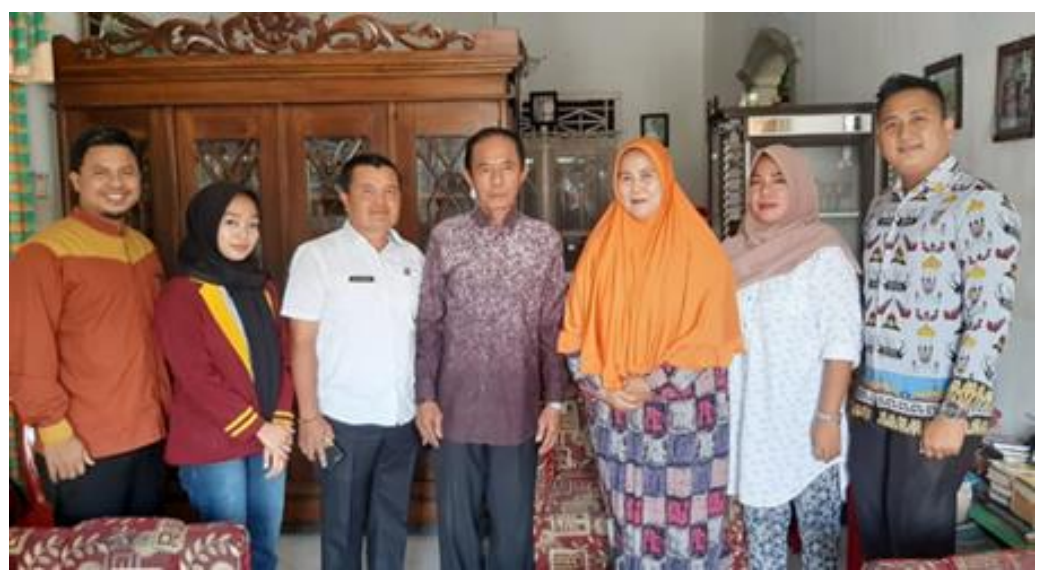

Gambar 2. Tim PKM berfoto bersama penutur sastra lisan Bapak Saiful Hambala (tengah) dan keluarga.

\section{Tahapan Inti}

\section{Perekaman Pertunjukan}

Langkah berikutnya adalah pelaksanaan kegiatan inti. Kegiatan diisi dengan perekaman video pertunjukan dengan menggunakan alat kamera DLSR. Kegiatan dilakukan pada 18 November 2020 di Kediaman penutur sastra lisan wawancan, Saiful Hambala di Desa Baturaja, Way Lima Kabupaten Pesawaran.

Dalam kegiatan tersebut penutur sastra lisan membacakan wawancan sebanyak 3 naskah yakni wawancan "Sejarah Singkat Kec. Way Lima", Wawancan Wawancan Nurdin-Ceri (Pampangan)" dan "Wawancan Jawabni Hulun Tuha". Hasil rekaman kemudian diedit menjadi sebuah video yang ditayangkan dalam kanal Youtube dan website. Video wawancan pertama memiliki durasi 4.05 menit.

Selain melakukan perekaman, para penutur juga diwawancarai seputar teks dan konteks wawacan yaitu sejarah proses pembuatan naskah wawancan, pembacaan wawancan, makna teks wawancan, dan profil penutur.

\section{Wawancan I}

Wawancan pertama yang berjudul wawancan "Sejarah Singkat Way Lima" dibuat pada tanggal 5 Juni 2003. Wawancan tersebut dibuat dalam rangka peresmian kecamatan baru yakni kecamatan Way Lima. 
Wawancan terdiri dari 15 bait sebelum kemudian direvisi menjadi 14 bait. Wawancan dibuat atas permintaan $\mathrm{H}$. Muchtar, tokoh masyarakat setempat. Diceritakan bahwa Desa Baturaja diputuskan sebagai lokasi kantor kecamatan. Proses pembangunannya sendiri dilakukan dengan cara kerja bakti masyarakat. Hal itu dapat dilihat dalam kutipan wawancan berikut ini.

\section{Pak minggu lom sebulan Pekhaga Kekhja Bakti \\ Induh di Tangebah Lamban \\ Kejuju ni Lokasi}

(Bait 10)

Terjemahan:

Empat minggu dalam sebulan

Selalu kerja bakti

Apa di depan rumah

Atau di dalam lokasi

Dalam pembangunannya, dikisahkan bahwa masyarakat Desa Baturaja merelakan secara ikhlas tanahnya dijadikan jalan kecamatan. Perhatikan kutipan wawancan berikut:

\section{Khanglaya kecamatan \\ Pitu meter bekhak ni \\ Se idang pekarangan \\ Sapa juga kedau ni}

(Bait 11)

Terjemahan:

Jalan ke kecamatan

Tujuh meter lebarnya

Masing-amasing pekarangan

Siapa saja pemiliknya

Mak moneh tian sungkan

Yu payu lillah hani

Pak mak tengan di badan

Di anak umpu nanti

(Bait 12)

Terjemahan:

Tak perlu ada yang sungkan Semua ikhlas karena Allah

Meskipun kita tak merasaan

Tapi kelak anak cucu nanti

\section{Wawancan II}

Wawancan kedua tentang pernikahan dengan judul 'Wawancan Nurdin-Ceri (Pampangan)". Wawancan dibuat tanggal 7 November 2020 atas permintaan keluarga pengantin Nurdin dari Desa Pampangan. Wawancan terdiri dari 19 bait. Dengan jumlah 4 baris pada masing-masing baitnya dan sajak a-b-a-b. Dalam wawancan diceritakan kisan calon pengantin. Selain itu disebutkan pernyataan-pernyataan permohonan pamit dan rida dari orang tua, permohonan maaf, Permohonan doa yang dipanjatkan agar pernikahan berjalan dengan lancar, bahagian dan sejahtera. Perhatikan kutipan berikut:

Anjo tangguh ku ganta 
Di mak ayah pokok ni Nyak hakhap kilu khila

Di Penguyunan kuti

Terjemahan:

Inilah sebagai pamitku

Dengan ibu dan ayah pokoknya

Aku mohon direlakan

Semua perawatannya

Atau pada kutipan berikut:

Mak ayah togok dija

Tangguh ku lawan kuti

Ampun bukhibu laksa

Mahap laheks batin ni

(Bait 19)

Terjemahan:

Ibu Ayah sampai di sini

Permohonan pamitku ini

Ampun beribu laksa

Mohon maaf lahir dan batin.

\section{Wawancan III}

Wawancan ketiga adalah "Wawancan Jawabni Hulun Tuha" yang berarti jawaban dari orangtua. Naskah ditulis 21 Agustus 1992. Naskah tersebut dibacakan setelah wawancan pernikahan dengan maksud membalas wawancan sebelumnya. Wawancan terdiri dari 17 bait dengan dengan jumlah 4 baris pada masing-masing baitnya dan bersajak a-b-a-b. Wawancan berisi nasihat dan doa dari orangtua kepada pengantin. Nasihat berisi tata cara berumah tangga mulai dari bagaimana suami dan isteri berbicara, bersikap antar sesamanya. Nasihat tersebut bersifat personal hanya ditujukan kepada suami dan isteri. Perhatikan wawancan berikut:

Haga pinyin di niku

Nguyun kon khumah tangga

Tingkah sakheta laku

Sopan santun ti jaga

(Bait 6)

Terjemahan:

Berhati-hatilah kamu

Mengurusrumah tanga

Tingkah beserta laku

Sopan santun dijaga

Atau kutipan berikut:

Terhadap di enggom mu

Dang salah tawai dia

Tantu mena pai niku

Ngakhubah tata cakha

(Bait 8)

Terjemahan: 
Terhadap suami isteri

Jangan salah ajak padanya

Tentu diawali kam

Merubah tata cara

Selain nasihat individual yang hanya berlaku di dalam kehidupan rumah tangga dalam wawancan juga disebutkan berbagai nasihat sosial berupa tata cara kehidupan sosial bermasyarakat seperti menjaga lisan dalam bersosialisasi dan tata cara terhadap tamu. Hal itu dapat dilihat pada kutipan sebagai berikut:

Dilom lamban sai tantu

Di luahan khena juga

Jaga sumba hawa mu

Kantu nyikhang cempala

(Bait 9)

Terjemahan:

Di dalam rumah yang tentu

Di luar begitu juga

Jaga lidah dan mulutmu

Supaya tidak melanggar aturan

Kantu kuti wat tamu

Ti tagu dang ki lupa

Sapa ajo do hamu

Ki kham mangkung wat tungga

(Bait 13)

Terjemahan:

Kalian ada tamu

Harus ditegur sapa

Segera keluarkan teko

Meskipun air putih saja.

Nasihat lainnya adalah nasihat spiritual mengatur hubungan antara manusia dengan tuhan. Diingatkan oleh orangtua agar anak-anaknya tidak melupakan salat lima waktu. Nasihat spiritual ini menunjukkan religiusitas keislaman masyarakat Lampung yang kuat. Bacalah kutipan berikut:

Kuti pandai di waktu

Ki minjak dang mawas ga

Sembahyang lima waktu

Dang haga sampai lupa

(Bait 12)

Terjemahan:

Kalian tahu terhadap waktu

Bangun subuh jangan lupa

Sembahyang lim awaktu

Jangan sampai kalian lupa

Atau pada kutipan:

Ki khadu manom hamu

Ti keboke jandila

Geluk hokhek kon lampu 
engok di waktu lima

(Bait 15)

Terjemahan:

Kalau sudah sore menurutmu

Tutup semua pintu jendela

Segera hidupkan lampu

Ingat salat lima waktu

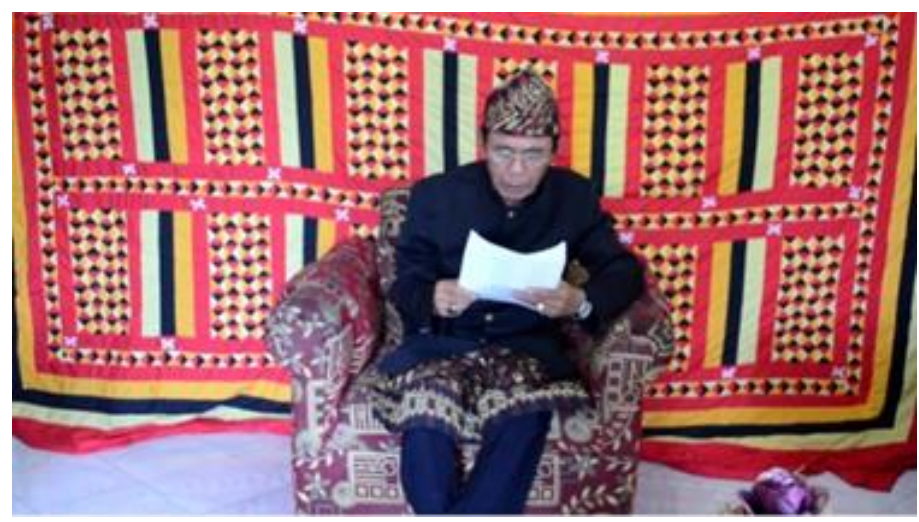

Gambar 3. Penutur Sastra lisan Saiful Hambala sedang membacakan naskah wawancan.

Nasihat-nasihat orangtua yang meliputi aspek personal, sosial, dan spiritual adalah perwujudan dari cara pandang masyarakat Lampung. Cara pandang tersebut termaktub dalam falsafah hidup masyarakat Lampung yang bernama Piil Pesenggiri. Menurut Fahrudin dalam Baharudin (2019:164) Piil Pesenggiri berelasi dengan eksistensi manusia dalam hubungannya dengan tuhan, dengan sesama manusia, dan dengan alam lingkungan. Filsafat Piil Pesenggiri mengandung nilai-nilai ketuhanan, humanistis, dan nilai-nilai kehidupan.

\section{Pengetikkan dan Penerjemahan sastra lisan}

Tahapan berikutnya adalah proses pengetikan teks wawancan dan penerjemahan. Teks wawancan yang asli berupa tulisan tangan pada kertas HVS atau folio bergaris. Kondisinya beragam ada yang masih terbaca jelas ada juga yang kurang terbaca akibat kertas yang kotor. Kondisi tersebut tentu saja mengkhawatirkan karena bisa saja sewaktu-sewaktu naskah-naskah tersebut hilang atau rusak. Oleh karena perlu adanya pengetikkan naskah untuk disimpan di komputer. Setelah kegiatan dilanjutkan dengan menerjemahkan teks wawancan dari bahasa Lampung ke Bahasa Indonesia. Hasil terjemahan ditampilkan dalam video dan website sehingga memudahkan proses pemaknaan terhadap sastra lisan. Penerjemahan dibantu oleh penutur wawancan Saiful Hambala dan bantuan Kamus Bahasa Lampung -Indonesia, Indonesia-Lampung karangan Abdulah (2008).

\section{Pembuatan Website}

Setelah didapatkan data berupa profil seniman, dokumentasi pertunjukan, dan penerjemahan sastra lisan, proses selanjutnya adalah pembuatan Website akan menampilkan peta sastra lisan, profil seniman, alamat, kontak seniman, video pertunjukan, dan artikel berita. Selain itu akan ditampilkan menu hubungi seniman, yang menghubungkan antara masyarakat dengan seniman, sehingga masyarakat dapat menghubungi seniman langsung melalui aplikasi jika ingin mengundangnya tampil. Judul website yaitu Pusat Dokumentasi Sastra Lisan Lampung dengan alamat website www.sastralisanlampung.info.

\section{Tahapan Evaluasi}

Setelah kegiatan inti, proses selanjutnya adalah evaluasi kegiatan dan evaluasi produk. Kegiatan evaluasi melibatkan budayawan, stakeholder pemerintah yakni Dinas Kebudayaan Pesawaran. Evaluasi dilaksanakan dalam bentuk focus discussion group (FGD). Kegiatan FGD mendiskusikan mengenai upaya-upaya apa saja yang dapat dilakukan ke depannya. Beberapa poin hasil FGD di antaranya perlu diadakan kegiatan pengumpulan naskah wawancan untuk didata, pengetikan, pengarsipan digital, pendirian dan pengelolaan sanggar, kegiatan pewarisan terhadap generasi muda, dan kegiatan sosialisasi yang massif kepada masyarakat terutama melalui media sosial 


\section{KESIMPULAN}

Dari hasil pelaksanaan dan pembahasan di atas, dapat disimpulkan sebagai berikut:

1) Terdapat beberapa permasalahan yang dialami para penutur sastra lisan seperti asrisp yang masih berupa tulisan tangan dengan kondisi tercecer, proses pewarisan tidak berjalan, kurangnya dukungan dan apresiasi terhadap penutur sastra lisan. Masalah perkembangan sastra lisan juga salah satunya ditentukan oleh proses pendokumentasian. Pada kenyataannya kesadaran akan pendokumentasian sastra lisan belum terbangun termasuk pemerintah daerah. Pendokumentasian yang dimaksud adalah pendokumentasian berbasis digital.

2) Pendokumentasian sastra lisan berbasis digital dilakukan dengan perekaman video pertunjukan, pengetikan naskah wawancan, dan penayangan video melalui youtube serta pembuatan website sebagai media penyimpanan arsip dan media penyampaian informasi yang lebih luas ke masyarakat.

3) Pemertahanan sastra lisan Lampung memerlukan usaha yang massif di antaranya dengan mengadakan kegiatan pengumpulan naskah wawancan untuk didata, pengetikan, pengarsipan digital, pendirian dan pengelolaan sanggar, kegiatan pewarisan terhadap generasi muda, dan kegiatan sosialisasi yang massif kepada masyarakat terutama melalui media sosial.

4) Proses pendokumentasian berbasis digital memerlukan waktu dan biaya yang cukup besar sehingga perlu adanya dukungan dana dari berbagai pihak terutama pemerintah.

\section{UCAPAN TERIMA KASIH}

Ucapan terima kasih disampaikan kepada Universitas Teknokrat Indonesia yang telah mendukung dan memfasilitasi kegiatan Pengabdian kepada Masyarakat melalui hibah internal.

\section{REFERENSI/DAFTAR PUSTAKA}

Abdullah. (2008). Kamus Bahasa Lampung-Indonesia, Indonesia-Lampung. Jakarta: Balai Pustaka.

Azhari, Yusuf Azis. (2018). Perubahan Tradisi Jawa (Studi Tentang Upacara Adat Pelaksanaan Perkawinan Suku Jawa Di Kepenghuluan Harapan Makmur Kecamatan Bagan Sinembah Raya Kabupaten Rokan Hilir). JOM FISIP Vol. 5 No. 1 - April 2018

Baharudin. (2019). Aksiologi Religiusitas Islam pada falsafah Hidup Ulun Lampung. International Jurnal Ihya 'Ulum Al-Din. Vol 21 No2 UIN Walisongo Semarang

Hambala, Saiful. (2003). Wawancan Sejarah Singkat Way Lima. Manuskrip.

Hambala, Saiful. (2020). Wawancan Nurdin-Ceri (Pampangan). Manuskrip.

Hambala, Saiful. (1992). Wawancan Jawab ni Hulun Tuha. Manuskrip.

Herdiani, Een. (2003). Bajidoran di Karawang: Kontinuitas \& Perubahan. Jakarta: Hasta Wahana.

Fakhrurozi, Jafar. (2019). Fungsi Wawancan dalam Upacara Adat Pengantin Lampung Saibatin. Jurnal Salaka Volume 1 Nomor 2 Tahun 2019

Ghassani, Maretha. (2019). Begawi Cakak Pepadun Sebagai Proses Memperoleh Adek pada Buay Nunyai di Desa Mulang Maya, 4 Juli 2019, Pesagi, Bandar Lampung.

Irawan, Edi. (2019). Digitalisasi Madrasah di Era Revolusi Industri 4.0: Refleksi Kegiatan Pengabdian Kepada Masyarakat di Kabupaten Ponorogo. E-DIMAS: Jurnal Pengabdian kepada Masyarakat, 10(2), 160-168

Isnaeni, Ahmad dan Kiki Muhamad Hakiki. (2019). Simbol Islam dan Adat dalam Perkawinan Adat Lampung Pepadun, Juni 2016, p-ISSN: 0853-9510; e-ISSN: 2540-7759, Kalam UIN Raden Intan, Bandar Lampung.

Jauhari, M, 18 Agustus 2020, wawancara di Ruang kerjanya di Kantor Dinas Pendidikan dan Kebudayaan, Pesawaran.

Pare, Selfina. (2013). Desain dan Implementasi E-Commerce Pada Toko As 88 Celluler Merauke, 2 Desember 2013, ISSN: 2089-6697, Mustek Anim HA Universitas Musamus.

Sukatman (2009). Butir-butir Tradisi Lisan Indonesia, Laksbang Pressindo, Yogyakarta.

Yudono, Jodhi. (2010). Sastra Lampung "Warahan" Terancam Punah, Kompas, Jakarta.

Yunus, Mahmud (2010). Artikel Antara, Jakarta. 